\title{
Dr. Shirley McBay
}

\section{Zerotti Woods}

Take a second, close your eyes, and imagine what it was like to be a woman in mathematics in 2018. Now imagine what it was like to be a woman in mathematics in 1966. Finish this exercise by imagining what it was like to be an African American woman in mathematics in 1966. This was the year that Dr. Shirley Mathis McBay graduated from the University of Georgia with her $\mathrm{PhD}$ in mathematics. She is the first African American to get a PhD from the University of Georgia in any field, and the first woman of any race to receive a $\mathrm{PhD}$ in mathematics from the University of Georgia. To put this into perspective, the University of Georgia's first PhD thesis in mathematics was in 1951. The school desegregated in 1961 and McBay enrolled in 1964 and graduated with her PhD in 1966. McBay became an educator, department chair, and pioneer of the mathematics department at Spelman College. She was a director at the National Science Foundation, dean at the Massachusetts Institute of Technology, and founder of an organization designed to assist minorities in their pursuit of education in STEM-related fields. I am astounded by her courage and willingness to be a trailblazer for students such as myself. I was recently afforded the opportunity to ask her a few questions through her sons Michael and Ronald McBay. I was also afforded the opportunity to visit her for an informal conversation. As a student who directly benefited from her sacrifices, it is my distinct pleasure to highlight some of her many accomplishments and give honor to such an amazing scholar.

McBay was born in Bainbridge, Georgia on May 4, 1935. According to [VH85], when McBay was ten years old, she competed against high school students in a mathematics competition-and won. Her mother knew that she was a very gifted student at a really young age, and although she

Zerotti Woods is a research mathematician at Johns Hopkins Applied Physics Laboratory. His email address is Zerotti . Woods@jhuap1. edu.

Communicated by Notices Associate Editor Daniel Krashen.

For permission to reprint this article, please contact: reprint-permi ssion aams.org.

DOI: https://dx.doi.org/10.1090/noti2048 was teased for being smart, her mother encouraged her to continue to excel in her studies. She graduated high school at the age of fifteen. Upon completion, she attended Paine College in Augusta, Georgia, where she earned a bachelor of arts in chemistry. She graduated summa cum laude at the young age of nineteen. She began teaching at Spelman College in Atlanta, Georgia upon graduation. While teaching at Spelman, she entered Atlanta University and earned a master of science in chemistry (1957) and a master of arts in mathematics (1958). It was at Atlanta University that she met and married Dr. Henry McBay. Dr. Henry McBay was a famous chemistry professor who taught at Morehouse College. While obtaining her masters degrees, she had one son (Michael). While she had a great interest in chemistry, and it only intensified while at Atlanta University (especially having taken a class from her soon-to-be husband at Morehouse), once she was a wife and had an infant son, she realized that studying chemistry had become less practical than studying mathematics. Chemistry meant spending long hours in the lab while mathematics could be studied anywhere, which meant that she could study at home while being a wife and mother.

Four years after receiving her masters she gave birth to her second son (Ronald) and was also accepted into the PhD program in mathematics at the University of Chicago. Her family was very instrumental in making it possible for her to pursue her PhD. Her older son was sent with her husband to live in Atlanta while her infant son was sent to Texas to live with her mother-in-law.

One day when McBay was on break from school and visiting Texas she noticed that her son was calling his grandmother "Mama." This did not sit well with McBay, and she knew she had to make a change. According to [War99], McBay received the United Negro College Fund Fellowship sponsored by the IBM Corporation in 1964, and transferred to the University of Georgia to complete her PhD in mathematics. I asked McBay if she ever felt scared on campus because of the hostile environment of a newly integrated college in the South. Her response surprised me because she told me that she does not have any recollection 




Pictured from left to right: ZerottiWoods, Dr. Shirley McBay, Michael McBay.

of any major incidents. She could only recall a few small things here and there. The stories of the first African Americans to ever enroll as undergraduates and the first African American to ever graduate from the University of Georgia were much different. Her son Ronald also said that she did not spend much time on campus. This may have been the reason that she did not get into many confrontations with other students. Her son Michael has a direct memory of visiting his mom in Athens. His recollection is that she was an off-campus boarder with a very supportive African American woman (Mrs. Appling) who lived nearby.

When asked about the relationship that she had with her advisor, she answered that her advisor Dr. Thomas Brahana was very supportive. In fact, she recalls that UGA was more supportive than the University of Chicago. McBay finished her PhD at UGA in 1966. Her thesis was titled "The Homology Theory of Metabelian Lie Algebras."

McBay was offered a position at UGA to teach mathematics, but she declined [VH85]. Immediately after earning her $\mathrm{PhD}$, she returned to Spelman as an associate professor of mathematics, and by 1970 she was also chair of the mathematics department [War99]. Her colleague and famous African American mathematician Dr. Etta Zuber Falconer said that she, McBay, and Dr. Gladys Glass were "the pioneers who built the mathematics department" at Spelman [War99]. As a result of McBay's leadership, in 1972, Spelman created the Division of Natural Sciences with McBay as the chairman [War99].

In 1975, after over fifteen years at Spelman, McBay took a position at the National Science Foundation and directed two national programs designed to increase minority participation in science and engineering.

In 1980, McBay became dean for student affairs at the Massachusetts Institute of Technology (MIT). While at MIT, she served as director of the MIT-based Quality Education for Minorities (QEM) Project for three years. The QEM Project conducted a thirty-month study of the educational problems of five underrepresented minority groups. The study made fifty-eight specific recommendations [Ros90].
In 1990, after ten years at MIT, McBay founded and became president of the QEM Network to replace the QEM Project. In her own words, "the purpose of the network is to implement the recommendations of the study." During her tenure as president, she served as the director of several science- and engineering-focused projects. These included several NSF-supported projects. "Today, QEM continues to be the premier organization for improving the quality of education for minorities, by providing technical assistance to MSIs (Minority Serving Institutions), funding internship opportunities for underrepresented students, and advocating for college and career readiness in STEM" [Net].

I asked McBay if she could have ever imagined that she would have such a large impact on the STEM world. Her answer was, "No. Some people have plans mapped out. I didn't. I just got the most out of whichever environment I was in. I never thought about being 'The First.' I wasn't one to dwell on the negative of a situation." This courage and selflessness paved the way for countless students to get the opportunities that she never had. Without trailblazers such as McBay, I am confident that students such as myself-a black kid from the inner city of Atlanta-would have never even dreamed that we too could succeed in earning a PhD in mathematics or any other STEM field. My final question for McBay was, "What advice would you give to current and future African Americans and women pursuing their $\mathrm{PhD}$ in mathematics?" Her response was, "Lay out a plan of action to have particular goals in mind. Do it in steps." Dr. McBay, thank you for your sacrifices and bravery. We still have a long way to go, but because of people like you we have come a long way and I am optimistic about the future.

\section{References}

[Net] QEM Network, Mission and History.

[Ros90] Brian Rosenberg, Dean McBay to Step Down, The Tech 110 (April 1990), no. 17.

[VH85] Mary Verheyden-Hilliard, Mathematician and Administrator, Shirley Mathis McBay, American Women in Science Biography, The Equity Institute, January 1985.

[War99] Wini Warren, Black Women Scientists in the United States, Indiana University Press, Bloomington, 1999.

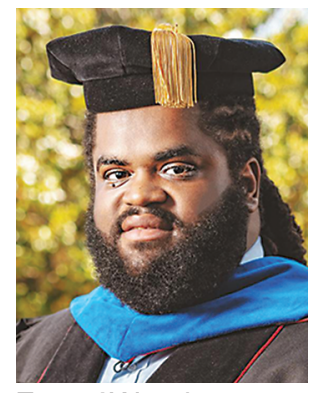

ZerottiWoods

\section{Credits}

Photos are courtesy of the author. 